\title{
Folic Acid Status in Premature Infants
}

\author{
T. M. VANIER and J. F. TYAS \\ From the Department of Haematology, St. Thomas' Hospital and Medical School, London S.E.1
}

Evidence is accumulating that premature infants run the risk of developing megaloblastic anaemia or other evidence of folic acid deficiency during the first two to three months of life (Gray and Butler, 1965; Shojania and Gross, 1964; Strelling, Blackledge, Goodall, and Walker, 1966).

The present study was carried out to compare the folic acid status of premature infants during the first eight months of life with that of full-term infants, and to see which of the former might be particularly vulnerable to folic acid deficiency. Detailed results on the folic acid status of full-term infants have recently been published (Vanier and Tyas, 1966).

\section{Material and Methods}

Twenty premature infants born at St. Thomas' Hospital or other centres in South London and transferred to our premature nursery were studied. Infants who appeared to be doing well between 3 and 6 days after birth were included in the study. Selection for followup was made as soon as the mother could be interviewed, and was based solely on her willingness and ability to co-operate, after the nature of the study had been explained. Of the original 24 infants tested neonatally, 2 had exchange transfusions and were excluded, and 2 could not be followed up.

There were 13 singleton births, 4 infants whose twin had died at or shortly after birth, and one set of triplets in the study.

No infant was excluded from the study because of infection, respiratory distress, or other untoward event, since it seems likely that the complications of prematurity enhance the risk of folic acid deficiency. No infant received a blood transfusion.

The following tests were carried out between the ages of 3 and 6 days, 2 and 3 months, and 6 and 8 months: $\mathrm{Hb}$, haematocrit, neutrophil lobe count, serum or plasma and whole blood folate. Formiminoglutamic (Figlu) acid and urocanic acid (UA) excretion after a histidine load were estimated at 2 to 3 and 6 to 8 months.

In addition, routine $\mathrm{Hb}$ levels and blood films were examined every 2 weeks during the stay in the premature nursery.

Tibial bone-marrow was obtained in three infants

Received June 23, 1966. whose routine haemoglobin was found to be lower than $7 \mathrm{~g} . / 100 \mathrm{ml}$.

While in the premature nursery, feeding consisted of maternal or 'bank' breast milk for the first few days followed by half-cream Cow and Gate milk. The latter was made up in hot boiled water, allowed to cool, and stored at $4^{\circ} \mathrm{C}$. until warmed to body heat before feeding during the next 24 hours. All infants received supplements of iron (sodium iron-edetate, Sytron $2 \mathrm{ml}$. b.d.) and vitamins $A, D$, and $C$ (Abidec 5 drops daily), from the age of 2 weeks. This régime was continued after the infants went home; semi-solid and solid foods and full cream milks being introduced gradually from 2 months onwards, depending on the infant's weight.

All methods were the same as those used in a study of normal full-term infants (Vanier and Tyas, 1966). The histidine load varied between 100 and $300 \mathrm{mg}$./kg.; during a pilot study it had been shown that this range was sufficient to stimulate excretion of pathological amounts of Figlu and UA in premature infants who showed other evidence of folic acid deficiency, without provoking a 'false positive' test in those without evidence of folate deficiency.

\section{Results}

The Table shows the changes in weight, $\mathrm{Hb}$, serum folate, whole blood folate, and folate in whole blood expressed as per $\mathrm{ml}$. red cells, neutrophil lobe count, and Figlu and UA excretion during the first 8 months of life.

Folate levels (Fig. 1 and 2). Neonatal serum and whole blood folate were higher than normal adult values and thus comparable to those of fullterm newborn babies. By the time the premature infants were 2 to 3 months old, however, the mean folate content of both serum and whole blood had fallen well below those of their full-term counterparts. 13 premature infants had serum levels below the normal lower limit of $5 \mathrm{~m} \mu \mathrm{g} . / \mathrm{ml}$., and $8 \mathrm{had}$ whole blood levels below the commonly accepted lower limit of $100 \mathrm{~m} \mu \mathrm{g} . / \mathrm{ml}$. RBC. The ages of the full-term and premature infants at this point were not exactly the same, since the former were tested between 3 and 4 and the latter between 2 and 3 months. The mean age of the premature infants 


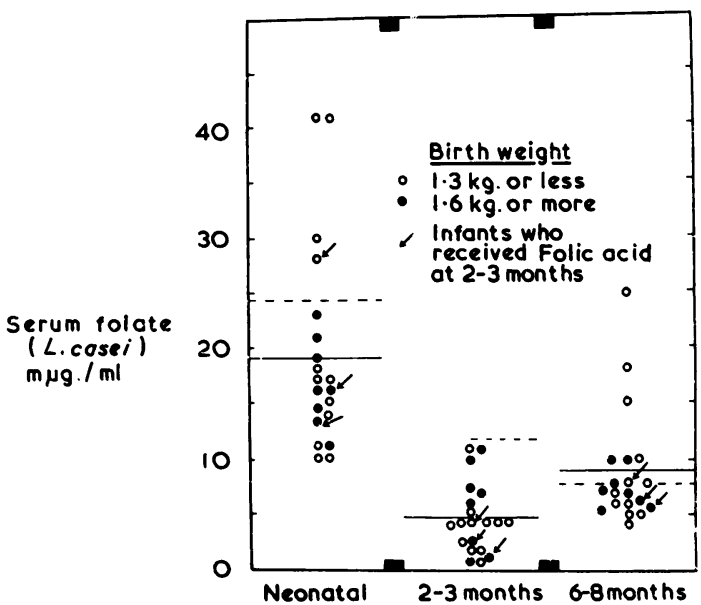

Fig. 1.-Serum folate levels in 20 premature infants. Horizontal line, mean values; interrupted horizontal line, mean values in full-term infants (Vanier and Tyas, 1966).

was 2.5 months and that of the full-term infants 3.25 months at the time of testing. We do not feel that this difference is likely to influence the figures to any significant extent.

By the age of 6 to 8 months both serum and whole blood levels were again comparable with those of full-term infants.

Excretion of Figlu and UA. Normal infants in the first year excrete up to $50 \mu \mathrm{g} . / \mathrm{ml}$. of Figlu or UA after a histidine load of 100 to $300 \mathrm{mg} . / \mathrm{kg}$. (Vanier and Tyas, 1966). Premature infants were not tested neonatally, but at 2 to 3 months: four infants excreted $100 \mu \mathrm{g} . / \mathrm{ml}$. and two excreted 200 $\mu \mathrm{g} . / \mathrm{ml}$. of Figlu, and three excreted $100 \mu \mathrm{g} . / \mathrm{ml}$. of

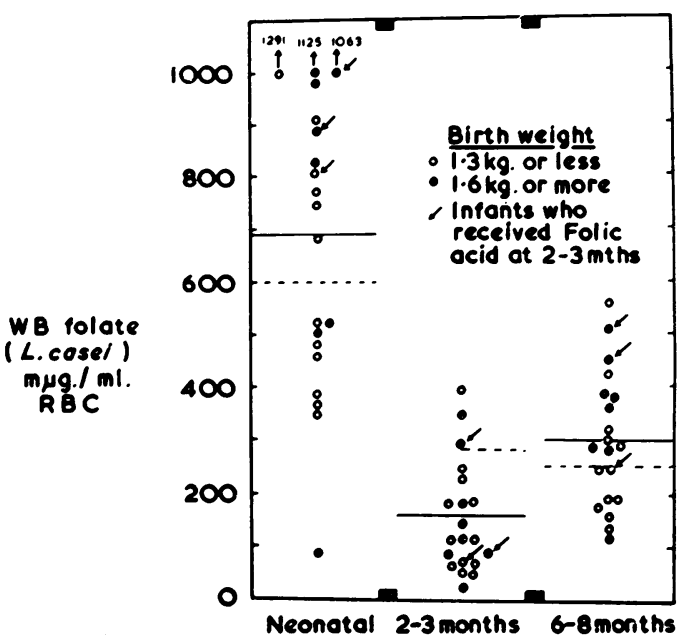

FIG. 2.-Whole blood folate levels in 20 premature infants. Horizontal line, mean values; interrupted horizontal line, mean values in full-term infants (Vanier and Tyas, 1966).

UA. Four of those with abnormal Figlu excretion put out normal amounts of UA, and one with abnormal UA excretion had a normal Figlu. All these infants had serum folate levels below $5 \mathrm{~m} \mu \mathrm{g}$./ $\mathrm{ml}$.

Neutrophil lobe counts. Between the ages of 2 and 3 months, four infants had $4 \%$ and two had $6 \%$ of hypersegmented neutrophils. These same infants showed an abnormal Figlu excretion.

Folate intake. Half-cream Cow and Gate milk was assayed for $L$. casei activity. A mean figure of $25 \mathrm{~m} \mu \mathrm{g} . / \mathrm{ml}$. was found before charcoal adsorption and $8 \mathrm{~m} \mu \mathrm{g} . / \mathrm{ml}$. after adsorption with activated

TABLE

Investigations on 20 Premature Infants

\begin{tabular}{|c|c|c|c|c|c|c|c|c|}
\hline \multirow{2}{*}{ Age } & \multirow{2}{*}{$\begin{array}{l}\text { Weight } \\
\text { (kg.) }\end{array}$} & \multirow{2}{*}{$\underset{(\mathrm{g} . / 100 \mathrm{ml} .)}{\mathrm{Hb}}$} & \multicolumn{3}{|c|}{ Folate ( $L$. casei) } & \multirow{2}{*}{$\begin{array}{l}\% \text { Cells } \\
\text { With } 5 \\
\text { or More } \\
\text { Lobes }\end{array}$} & \multicolumn{2}{|c|}{ Urinary } \\
\hline & & & $\underset{(\mathrm{m} \mu \mathrm{g} . / \mathrm{ml} .)}{\text { Serum }}$ & $\begin{array}{l}\text { Whole Blood } \\
\text { (mug./ml.) }\end{array}$ & $\begin{array}{l}\text { Whole Blood } \\
\text { (mug./ml. RBC) }\end{array}$ & & Figlu & $\begin{array}{l}\text { Urocanic } \\
\text { Acid }\end{array}$ \\
\hline Newborn $\left\{\begin{array}{l}\text { Mean } \\
\text { Range }\end{array}\right.$ & $1 \cdot 1 \cdot 4$ & $\begin{array}{c}16 \cdot 4 \\
14 \cdot 6-18 \cdot 2\end{array}$ & $\begin{array}{r}19 \cdot 2 \\
10-41\end{array}$ & $\begin{array}{c}343 \\
62-602\end{array}$ & $\begin{array}{c}689 \\
88-1291\end{array}$ & $\begin{array}{l}0 \cdot 3 \\
0-3\end{array}$ & - & - \\
\hline 2-3 mth. $\left\{\begin{array}{l}\text { Mean } \\
\text { Range }\end{array}\right.$ & $\begin{array}{l}2 \cdot 9 \\
1 \cdot 8-4 \cdot 0\end{array}$ & $\begin{array}{l}8 \cdot 8 \\
6 \cdot 4-11 \cdot 5\end{array}$ & $\begin{array}{r}4 \cdot 8 \\
1-11\end{array}$ & $\begin{array}{c}41 \\
16-90\end{array}$ & $\begin{array}{c}164 \\
26-394\end{array}$ & $\begin{array}{l}1 \cdot 8 \\
0-6\end{array}$ & $6+$ & $3 t$ \\
\hline 6-8 mth. $\left\{\begin{array}{l}\text { Mean } \\
\text { Range }\end{array}\right.$ & $4 \cdot 6 \cdot 1$ & $\begin{array}{l}11 \cdot 6 \\
10-13 \cdot 6\end{array}$ & $\begin{array}{c}8 \cdot 9 \\
4 \cdot 1-28\end{array}$ & $\begin{array}{c}114 \\
48-200\end{array}$ & $\begin{array}{c}299 \\
139-558\end{array}$ & $\begin{array}{l}0 \cdot 1 \\
0-1\end{array}$ & $0 t$ & $0 t$ \\
\hline $\begin{array}{r}\text { Normal } \\
\text { Full-term } \\
\text { Infants } \\
\text { 3-4 mth. }\end{array}\left\{\begin{array}{l}\text { Mean } \\
\text { Range }\end{array}\right.$ & $\begin{array}{c}6 \cdot 1 \\
4 \cdot 6-7 \cdot 4\end{array}$ & $10 \cdot 6-14$ & $\begin{array}{l}12 \cdot 2 \\
5-30\end{array}$ & $\begin{array}{c}99 \\
20-318\end{array}$ & $\begin{array}{c}283 \\
110-489\end{array}$ & $\begin{array}{c}0 \cdot 58 \\
0-3\end{array}$ & ot & of \\
\hline
\end{tabular}

* Vanier and Tyas (1966). † Numbers of cases showing abnormal excretion. 
charcoal (Vanier and Tyas, 1966). The actual $L$. case $i$ active folate content was therefore of the order of $17 \mathrm{~m} \mu \mathrm{g} . / 100 \mathrm{ml}$. or $17 \mu \mathrm{g}$./litre.

This means that an infant weighing $2 \mathrm{~kg}$. might have a folate intake of as little as $7 \mu \mathrm{g}$./day.

\section{Case Histories}

The following infants are considered in detail since their $\mathrm{Hb}$ fell below $7 \mathrm{~g}$. $/ 100 \mathrm{ml}$.

Case 1. Male infant, caesarean section, birthweight $1.2 \mathrm{~kg}$., had difficulty in feeding, and episodes of diarrhoea during the first two months. There was slow weight gain: the gain at 2 months being only half the mean gain. At the age of 2 months $\mathrm{Hb}$ was $6.4 \mathrm{~g}$. $/ 100 \mathrm{ml}$., 5-lobe neutrophils $4 \%$, serum folate $4 \mathrm{~m} \mu \mathrm{g}$. $/ \mathrm{ml}$., whole blood folate $84 \mathrm{~m} \mu \mathrm{g} . / \mathrm{ml}$. RBC, serum B12 $400 \mu \mu \mathrm{g} . / \mathrm{ml}$., Figlu $100 \mu \mathrm{g} . / \mathrm{ml}$., UA $25 \mu \mathrm{g} . / \mathrm{ml}$.

There was delay in examining the bone-marrow, and meanwhile the infant was started on Nutramigen (a milk product with hydrolysed protein) because of the persistent feeding difficulty. When he was seen again four days after Nutramigen was introduced, a palpable spleen was noted for the first time. The peripheral blood showed striking changes (Fig. 3). There were 69 nucleated red cells per 100 white cells, reticulocytes $22 \%$. A bone-marrow examination that day showed giant metamyelocytes but only minimal maturation defect of the late normoblasts. The $\mathrm{Hb}$ rose and the spleen became impalpable. It seems possible that the transient enlargement was due to sudden erythropoietic activity involving extramedullary sites as well as the bone-marrow.

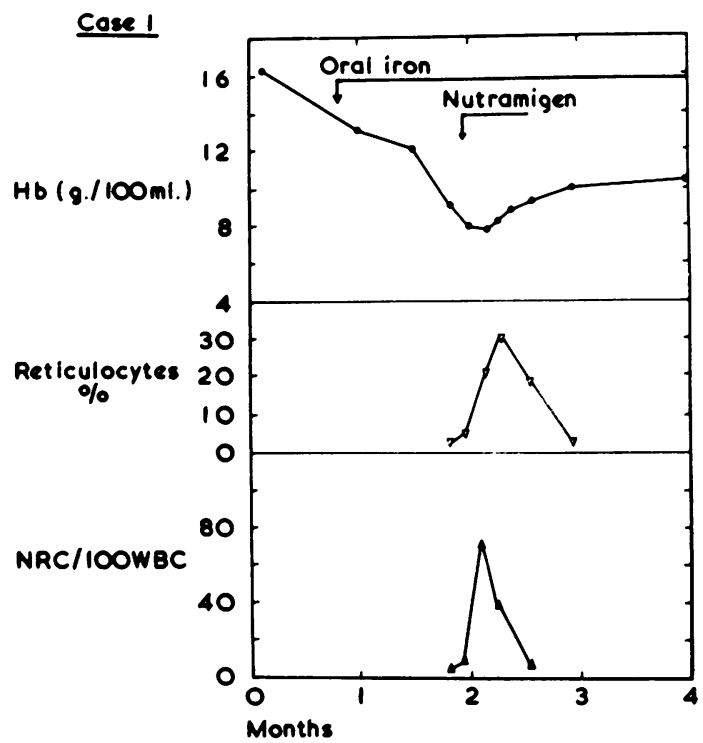

Fig. 3.-Effect of Nutramigen on nucleated red cells (NRC) and reticulocytes in peripheral blood, and on haemoglobin level (Case 1).
Nutramigen has been found to contain more than $100 \mu \mathrm{g}$./litre of folate (L. casei) activity (Naiman and Oski, 1964), and there seems little doubt that this was the erythropoietic stimulant.

Case 12. A male infant, one of twins, birthweight $2 \mathrm{~kg}$., made fairly satisfactory progress during the first two months but then developed gastro-enteritis and pneumonia. A few days after readmission he was found to have $\mathrm{Hb} 6 \cdot 1 \mathrm{~g} . / 100 \mathrm{ml}$., 5-lobe neutrophils $6 \%$, serum folate $2.5 \mathrm{~m} \mu \mathrm{g}$. $/ \mathrm{ml}$., whole blood folate $293 \mathrm{~m} \mu \mathrm{g}$. ml. RBC, serum B12 $360 \mu \mu \mathrm{g} . / \mathrm{ml}$., Figlu $200 \mu \mathrm{g} . / \mathrm{ml}$., UA $100 \mu \mathrm{g} . / \mathrm{ml}$. Bone-marrow showed normoblastic hyperplasia with some giant metamyelocytes.

Due to a misunderstanding on the part of his mother this infant did not receive iron supplements between the age of 1 and 2 months. Fig. 4 shows that there was a slight reticulocytosis associated with antibiotic therapy for the infections. Treatment with folic acid, however, resulted in an outpouring of normoblasts into the peripheral blood and a reticulocytosis of $18 \%$. Hb rose only slowly, possibly because of a more marked degree of iron deficiency.

Case 19. A male infant, one of twins, caesarean section, birthweight $1.8 \mathrm{~kg}$., needed resuscitation for 30 minutes before the first spontaneous breath. There was feeding difficulty during the first two months and slow weight gain, the gain at 2 months being only half the mean gain for the group. He was found to have $\mathrm{Hb}$ $6.9 \mathrm{~g}$. $/ 100 \mathrm{ml}$., 5-lobe neutrophils $6 \%$, serum folate $1.5 \mathrm{~m} \mu \mathrm{g} . / \mathrm{ml}$, whole blood folate $87 \mathrm{~m} \mu \mathrm{g} . / \mathrm{ml}$. RBC, serum B12 $400 \mu \mu \mathrm{g}$./ml., Figlu $200 \mu \mathrm{g} . / \mathrm{ml}$., UA $100 \mu \mathrm{g}$./ $\mathrm{ml}$. Bone-marrow: early megaloblastic changes with

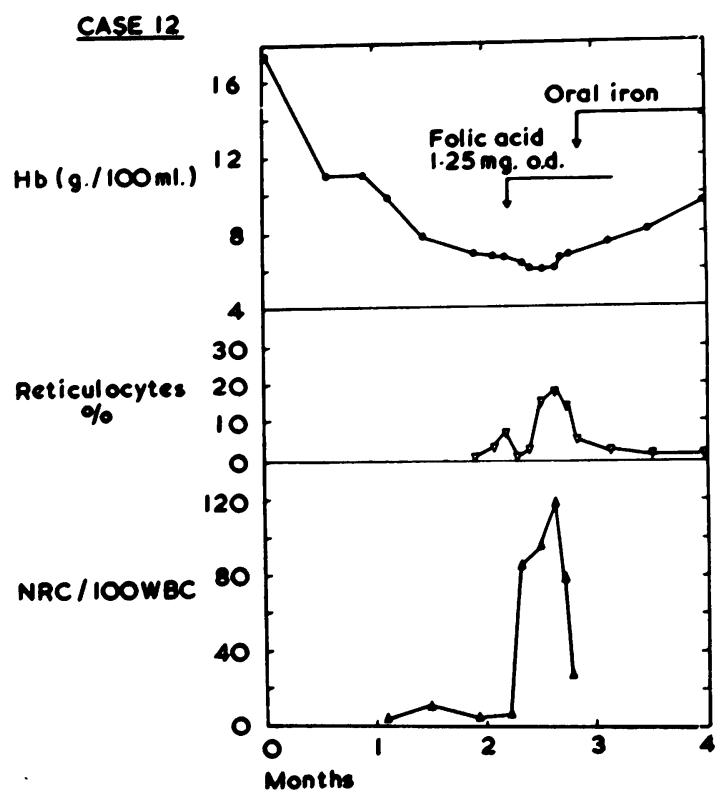

FIG. 4.-Effect of oral folic acid (Case 12). 


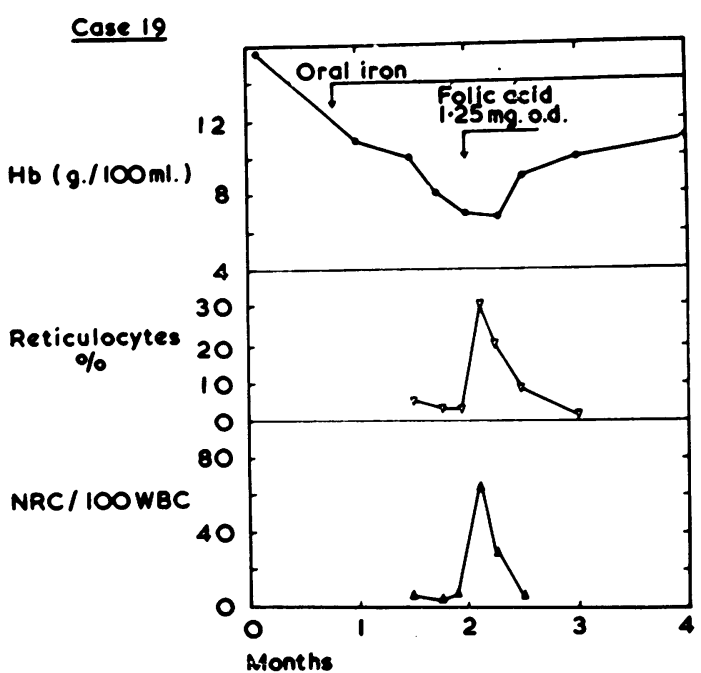

FIG. 5.-Effect of oral folic acid (Case 19).

giant metamyelocytes. As in the other two cases, oral folic acid initiated a brisk erythropoietic response and a rise in $\mathrm{Hb}$ (Fig. 5).

\section{Discussion}

The newborn premature, like the full-term infant, has high serum and whole blood folate levels compared to normal values in adults.

The fall during the first weeks of life is greater in premature infants, and the most dramatic fall occurs in those of lowest birthweight. This confirms the findings of others that birthweight does not influence levels in the immediate neonatal period, but that the lower the weight at birth the more marked the fall in the first few weeks (Shojania and Gross, 1964) and the more likely that megaloblastic anaemia will supervene (Strelling et al., 1966).

The twins and triplets in this series showed no difference in neonatal levels over singleton births, nor did two twin infants or the triplets show a greater degree of folic acid deficiency than singletons. The fact that two other twins were among the three babies with lowest $\mathrm{Hb}$ levels seems due to their stormy passage during the first weeks of life, rather than to the fact that they were products of multiple pregnancies.

Deficiency of folic acid in premature infants is most likely due to an intake which is inadequate to meet growth requirements. The folate content of the milk normally used in the premature nursery is even lower than that of the full cream milk usually offered to full-term infants (Vanier and Tyas, 1966) and the growth requirements of the former are greater. Premature infants with the lowest birthweights are those in whom requirements of folic acid for growth are likely to be the highest, they are also those in whom complications such as infection and feeding difficulties (resulting in loose stools and possible malabsorbtion) may enhance the risk of deficiency. Infection makes a sudden demand on folate stores which cannot be met, and in the fullterm infant may precipitate a deficiency of greater or lesser degree. The stores of the premature baby appear to be even more precarious.

It is noteworthy that the 3 infants who had the lowest $\mathrm{Hb}$ levels and who responded to folic acid in this series had had a stormy passage during the first few weeks of life, either because of feeding difficulties or because of infection.

In this study there was no relation between $\mathrm{Hb}$ and serum or whole blood folate when both these parameters had reached the lowest levels at 2 to 3 months of age. This agrees with the findings of Shojania and Gross (1964). Windmiller, Whitaker, and Sartain (1963) reported that the addition of folic acid to the diet of premature infants failed to influence $\mathrm{Hb}$ levels. This state of affairs is understandable if the folic acid deficiency is not severe enough to depress erythropoiesis, and this is probably the case in most infants.

It is possible that iron deficiency plays some part in precipitating folate deficiency in premature infants, though the former occurs earlier than iron deficiency usually does. Iron deficiency is certainly likely to conceal the morphological changes of megaloblastic anaemia. The infant (Case 12) in whom absolutely no megaloblastic changes were found was the one who had failed to receive iron supplements.

At present, therefore, there is little evidence that supplemental folic acid will influence the general progress or $\mathrm{Hb}$ levels of most premature infants. On the other hand, certain babies would benefit from such supplements: these include infants of very low birthweight (less than $1.5 \mathrm{~kg}$.), infants who 'fail to thrive' during the first few weeks, and those who suffer from any infection.

\section{Summary}

Twenty premature infants born in London were followed during the first 8 months of life in order to compare various parameters related to folic acid metabolism with those of full-term infants.

It was found that whereas both groups started their neonatal life with high serum and whole blood folate levels, two-thirds of premature infants showed 
some evidence of folate deficiency by the age of 2 to 3 months. The three premature infants with lowest haemoglobin levels had a marked erythropoietic response to folic acid.

Low folate stores are primarily due to an inadequate intake.

Our thanks go to the Nursing Staff of the Premature Nursery and Mothercraft Department of St. Thomas's Hospital for their help in organizing this study, to Dr. D. Cottom and Dr. B. D. R. Wilson for permission to study infants under their care, and to the mothers whose interest and co-operation allowed us to prolong the study after their babies were taken home.

\section{REFERENCES}

Gray, O. P., and Butler, E. B. (1965). Megaloblastic anaemia in premature infants. Arch. Dis. Childh., 40, 53.

Naiman, J. L., and Oski, F. A. (1964). The folic acid content of milk: revised figures based on an improved assay method. Pediatrics, 34, 274.

Shojania, A. M., and Gross, S. (1964). Folic acid deficiency and prematurity. F. Pediat., 64, 323.

Strelling, M. K., Blackledge, G. D., Goodall, H. B., and Walker, C. H. M. (1966). Megaloblastic anaemia and whole-blood folate levels in premature infants. Lancet, 1, 898.

Vanier, T., and Tyas, J. F. (1966). Folic acid status in full term infants during the first year of life. Arch. Dis. Childh., 41, 658.

Windmiller, J., Whitaker, J., and Sartain, P. (1963). The influence of exogenous folic acid on the early anaemia of prematurity. Society for Pediatric Research, May 1, 1963, Atlantic City, N.J. (Abstr.). 